Tori, 33: 51-65, 1984.

コサギの冬腒に括ける就・離侍行動と気象要因*

伊 藤 信 義

大阪市旭区 伊藤病院

\title{
The Effect of Weather on the Roosting Behaviour of the Little Egret Egretta garzetta in Winter
}

\author{
Shingi ITOH
}

Itoh Hospital, 2-24-20, Shinmori, Asahi-ku, Osaka 535

わが国で繁殖するシラサギ Egretta 属のらち，ダイサギ Egretta alba とチュウサギ E. intermedia はほとんどが夏鳥である (日本鳥学会, 1974). ユサギ E. garzetta は, 留鳥な いし漂鳥として越冬するものが多いが,一部は冬を避けてフィリピンまで渡る(環境庁, 1978)．私はコサギが非繁殖期に就侍前集合をすることを報告したが（伊藤，1984）, 本報 では日本の冬の気象に対してコサギの就・離侍行動がどのように適応しているかについて 述べてみたい.

コサギの就・離侍と気象要因に関する研究は, これまでに定性的な調查結果（柿沢・柿 沢，1973）ないし断片的記載（重野，1983）があるだけである. 私は, 就・離侍前後の一 連の行動と照度・日没ないし日の出の時刻・気温の関係を定量的に検討した. その結果, コサギの冬侍に特ける就・離侍行動に対して照度がひきがね的に作用し, 気温が低いほど 就・離㭙を早めることが明らかになった.

\section{調査地および調査方法}

採食地から帰ってきたコサギの多くがいったん一定の場所（集合所という）に集まって 集団で就侍する行動を就侍前集合（以下，単に集合という），集合をせず直接に就侍する 行動を直接就侍と呼ぶことにしたい（伊藤，1984).

調査地は, コサギの集合に関する調査を行った 7 か所（伊藤, 1984）のうちで最も観察 しやすい奈良市尼ケ辻町・垂化天皇陵を選んだが, 就侍行動と天候との関係の考察には, 岡山市百間川河口 (1981 年 10 月 7 日, 17 日, 18 日) と滋賀県坂田郡山東町 •三島池 (1982 年 11 月 28 日, 1983 年 1 月 9 日), 同高島郡牧野町中庄（1982 年 7 月 25 日）での合計 6 日 間の結果も加えた。

垂仁天皇陵は, 周濠に囲まれた周囲 $315 \mathrm{~m}$, 面積約 $68,000 \mathrm{~m}^{2}$, 標高 $80 \mathrm{~m}$ の前方後円 墳で, スギ・ヒノキ・クス・カシ・サカキ・アシビなどの老木に覆われている. この昳で はタイプ B·C の集合が行われたが，就侍群の $81.2 \%$ は南の方向から帰った (伊藤, 1984). ここに就侍するサギはほとんどがコサギであるが, 若干数のダイサギ・チュウサギも含ま れ，ほかにクロトキ Threskiornis melanocephalus 1 羽が集合と就侍をともにした. な拈,

*この論文の要旨は, 日本鳥学会 1983 年度大会 (東京) で講演ならびにポスターにより発表した. 
補助的に観察した 3 か所の環境については伊藤 (1984) を参照されたい.

就侍行動と気象要因については，1982 年 12 月より 1983 年 4 月まで 22 回 (12 月 5 日， 12 日； 1 月 22 日， 29 日， 30 日； 2 月 5 日， 6 日， 19 日， 20 日； 3 月 2 日， 5 日， 6 日， 12 日， 19 日， 20 日， 23 日， 24 日； 4 月 2 日， 5 日， 9 日， 13 日，20日）調查 した結果のうち, 1 月 22 日以後の分について, 定量的に検討した. 調査は, 遅くとも 13 時までに現地へ到着し, 飛来するサギの集合所への到着, 同所から侍への出発, および直 接就侍ごとの個体数・時刻・照度・天候などを記録し, 暗くなってカウントが不可能とな るまで行った.

次に, 離侍行動と気象要因についての調査は, 1983 年 1 月から 5 月まで 11 回 (1 月 23 日， 30 日; 2 月 6 日， 20 日; 3 月 6 日， 13 日， 20 日； 4 月 6 日， 10 日， 17 日； 5 月 19 日）行ったが, 定量的検討を加光たのは 4 月 10 日までの 9 回分についてである. また， 3 月 6 日と 13 日の夜間 (0-1 時) に, 侍から聞えてくるコサギの鳴き声を調べた. 離侍は一斉に短時間で行われるため, 個体数の正確なカウントが不可能であったので, 調査前夜の就䏝数をもって離侍数とみなすことにした. 調查は, 周濠を介して時から約 $40 \mathrm{~m}$ 隔てた堤防上で, 日の出 2 時間前に始め, まず侍部位から聞えてくるコサギの鳴き 声を調べ，ついで目覚め以後の行動を観察し，離侍の開始後はその個体数を記録した. 照 度の測定は 1 分ごとに行った. また, 2 月 20 日朝, 侍の南方 $1,200 \mathrm{~m}$ 地点の通過状況を 調べた.

奈良市と岡山市の日没と日の出の時刻・最高および最低気温・風向・風速は奈良気象台 奈良観測所および岡山気象台岡山観測所の観測結果によった.

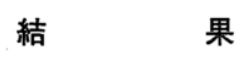

\section{（1）就侍行動と日没時刻}

i) 就侍前集合開始時刻と日没時刻

集合開始時刻は，春に向から日没時刻の遅れとともに遅くなり (Fig. 1)，1-2 月には 14 時台（観察 7 回中 5 回), 3 月は 15 時台（同 8 回中 5 回), 4 月には 17 時台 (同 5 回中 4 回) が多く, 平均して日没前 125.3 分 (19-176 分, $\mathrm{SD}= \pm 48.3$ 分, $\mathrm{N}=20)$ であった. 集合開始時刻と日没時刻との間には有意の相関 $(r=0.686, P<0.001, N=20)$ が認められ た.

ii) 就時開始および終了の時刻と日没時刻

就侍開始時刻は, 平均して日没後 3.3 分 (日没前 25 分一日没後 13 分, $\mathrm{SD}= \pm 9.7$ 分, $\mathrm{N}=20$ ), 就侍終了時刻は日没後平均 19.6 分 (日没後 6-33 分, $\mathrm{SD}= \pm 7.2$ 分, $\mathrm{N}=20$ ) であった (Fig. 1).

就侍開始時刻も日没時刻との間には高い相関があり $(r=0.852, P<0.001, \quad \mathrm{~N}=20)$, 量 天・雨天には早め, 晴天には遅めとなりながら，日没時刻と相前後した (Fig. 2).

\section{（2）就侍行動と照度}

i) 就侍前集合と照度

集合が始まるときの照度は 2,820-32,300 lux で, 変動幅が大きく; 10,000 lux 以下の日 が $35.0 \%$, 10,001-14,000 lux の日が 45.0\%，14,001 lux 以上の日が 20.0\%であった (Fig. 3). 集合開始時の照度と最高気温の間には, 有意の相関がみられなかった $(r=-0.046, P$ 


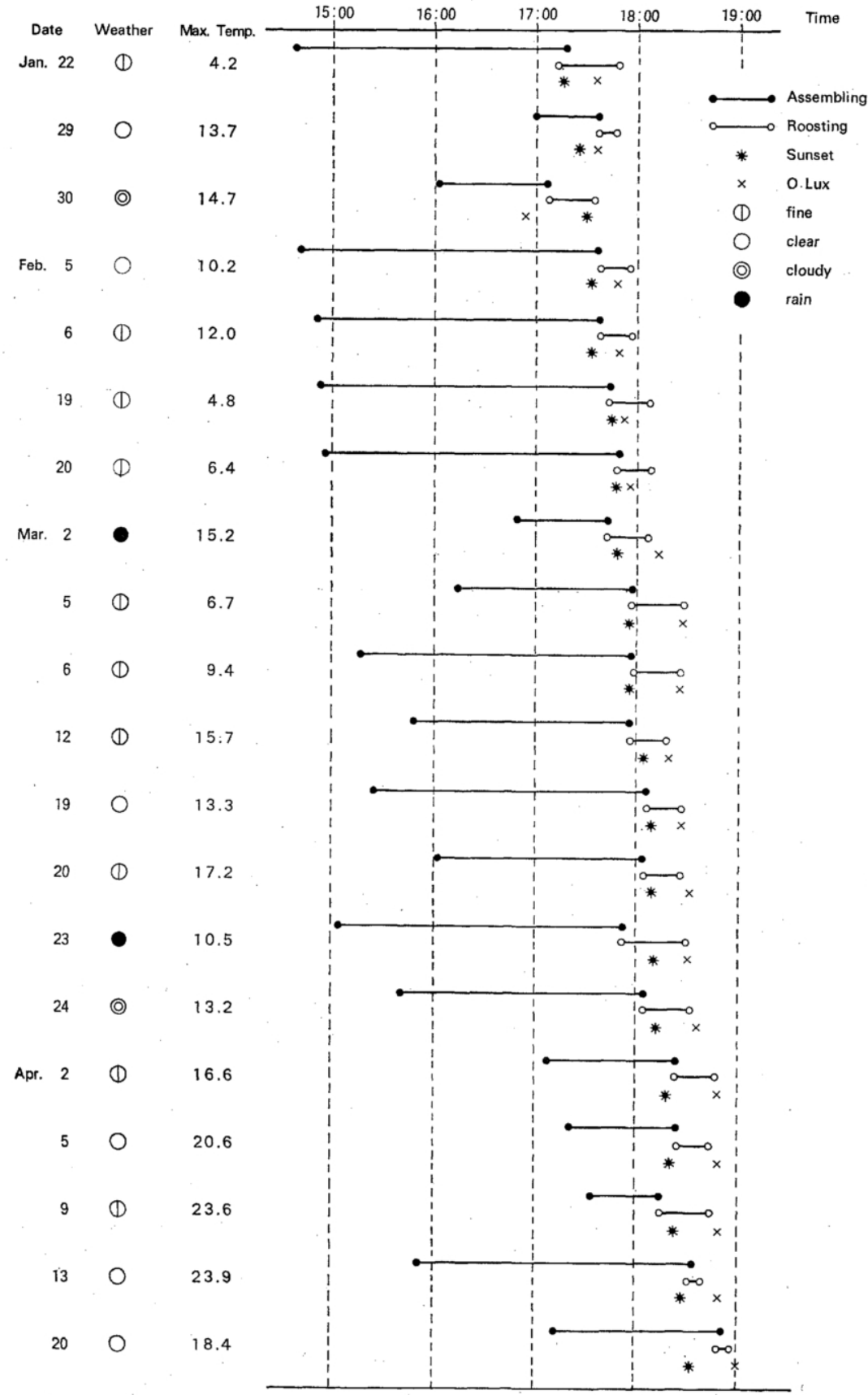

Fig. 1. Times of pre-roosting assemblies and roosting of the Little Egret in relation to sunset. 


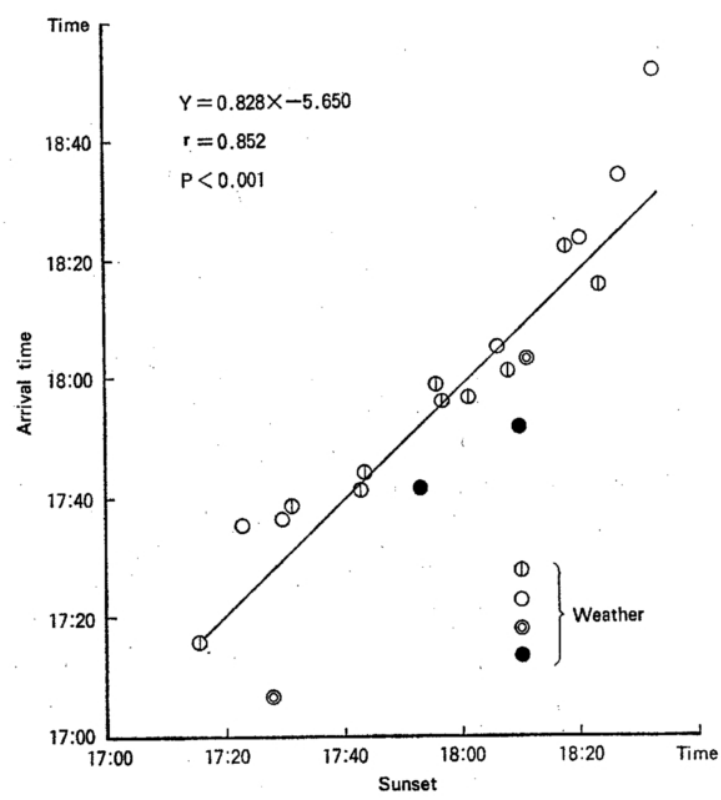

Fig. 2. The relationship between arrival at the roost and sunset.

$>0.05, \mathrm{~N}=20$ ).

集合数の $70 \%$ が集合したときの照度は, $75.0 \%$ の観察日で 700 lux 以下であった (Fig. 3). そして，2,500 lux 以下の時間帯（集合時間の 25.0-29.8\%にあたる）に集合数の 90.4-98.2\% が集合した.

ii) 就埘開始時の照度

就墛開始時の照度は平均 $355.2 \operatorname{lux}(0-2,406 \mathrm{lux}, \mathrm{SD}= \pm 646.2$ 分, $\mathrm{N}=20)$, 調查日の最高 気温は平均 $13.4^{\circ} \mathrm{C}\left(4.2-23.9^{\circ}, \mathrm{SD}= \pm 6.0^{\circ}, \mathrm{N}=20\right)$ で，両者には有意の負相関 $(\mathrm{r}=-0.554$, $P<0.02, \mathrm{~N}=20)$ があり，その日の気温が低いほど就侍開始時の照度が高い，すなわち就 侍開始時刻が早くなる傾向が認められた.

iii) 就侍終了時の照度

就持終了時（直接就侍が終るとき）の照度は平均 4.7 lux (0-28 lux, $\mathrm{SD}= \pm 8.4 \mathrm{lux}, \mathrm{N}=$ 20)であった，そして，3 月 12 日までは 1 日（3 月 2 日）を除き $0 \operatorname{lux}$ 以下で， 3 月 19 日以後はすべて 0 lux 以上 (0.4-21.8 lux) であった (Fig. 3). 可照時間の延長に伴い採食 時間が伸びて採食度が向上し, かつ採食度の個体差が縮まるために, 就侍終了時刻が次第 に早くなるのであろう．

（3）就侍行動と気温

i) 就侍前集合飞要する時間と気温

集合所要時間（集合開始から就侍開始まで）は平均 128.0 分（伊藤，1984）で，最高気 温との間に負の有意相関が認められた $(r=-0.470, P<0.05, N=20) .4$ 月に集合所要時 間の短縮傾向が認められたが，これは気温上昇・可照時間延長に伴い採食度での個体差が 縮小することや集合数が減少するためと推測される. 


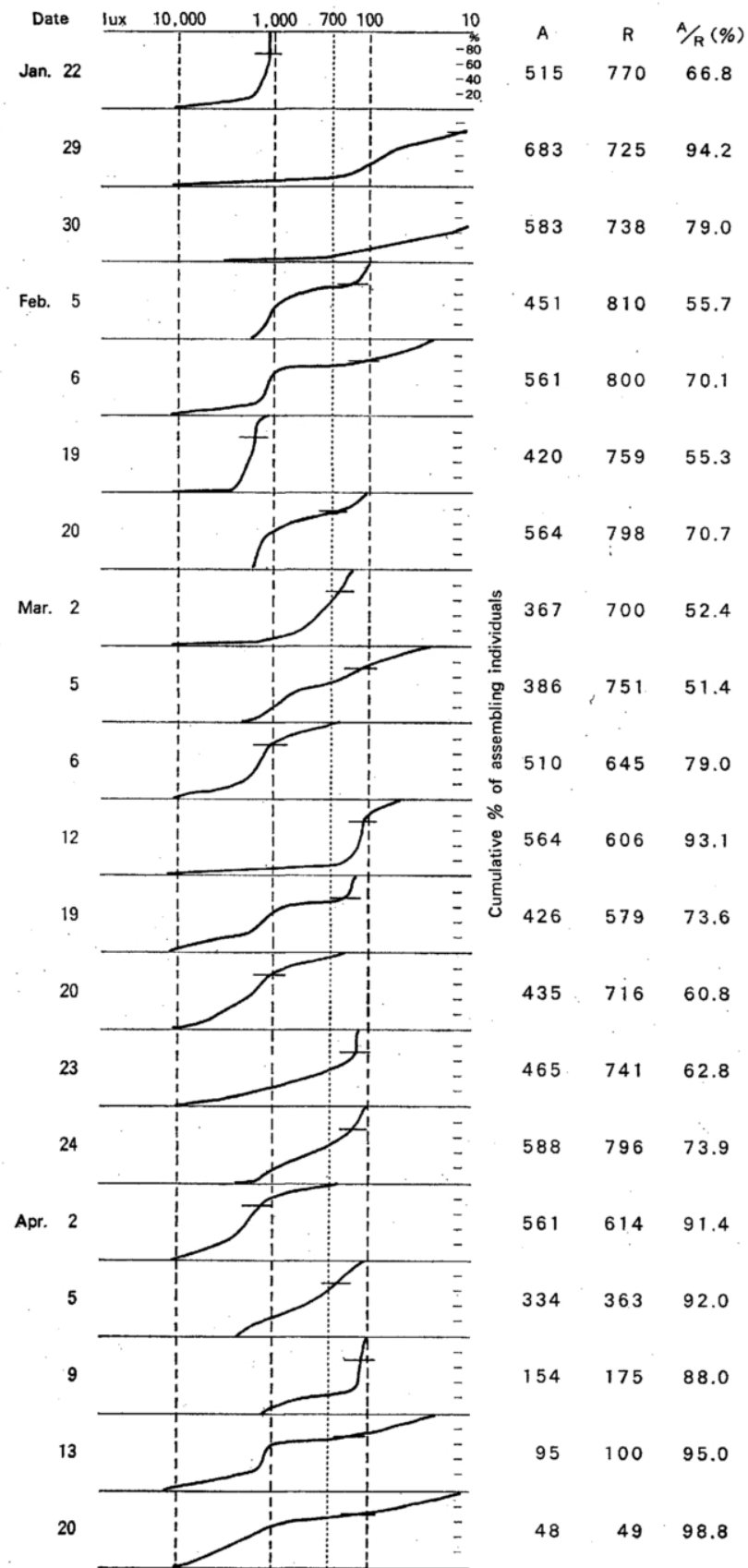

Fig. 3. Cumulative patterns of percentages of pre-roosting birds in relation to light intensity. Horizontal bars represent the $70 \%$ level. Total numbers of pre-roosting (A) and roosting birds $(\mathbf{R})$ are shown in the right column. 
集合所要時間と集合率・A/R\%（集合数の就侍総数に対する比率）の相関は有意でない が $(\mathrm{r}=-0.351, P>0.05, \mathrm{~N}=20)$, 負の数值が得られたことは, 寒い日には集合所要時間 が長いのに集合率が却って低い傾向があることを暗示している.

ii) 就侍前集合所へ飛来の回数・個体数と気温

集合所への飛来回数とその日の最高気温との間には有意の負相関がみられ $(\mathrm{r}=-0.605$, $P<0.02, N=20)$, 気温が高いほどより少ない回数で, 次項で述べるとおりより多くの個体 が集合し, 逆に気温が低く集合率の低いとき飛来回数が多く, したがって 1 回ごとの飛来 の個体数が少ない.

採食地での群れ行動は慨条件によっても異なるが, 朝の採食地への出発が後述（p. 60) の如く厳寒の日にとくに分散的であること, 冬季日中はあまり移動しないこと（山岸ほ か, 1980) からみて, 養魚池の水抜き後（採食の好条件）のような大きな群れ行動を招く 採食条件での変化がない限りは, 気温が低い注ど採食地で分散する傾向があることを示唆 する.

iii) 就侍前集合率と気温

集合率とその日の最高気温との間には有意の相関がみられ $(\mathrm{r}=0.659, P<0.01, \mathrm{~N}=20)$, 気温が高いほど集合率が高い傾向が示された. 4 月に入り最高気温がとみに上昇するとと もに集合率は平均值を上回り，88.0\% 以上となった (Fig. 3).

iv） 就侍前集合開始から就侍終了までの時間と気温

集合開始から就侍終了までの時間は 155.8 分で (伊藤, 1984), 最高気温との間に負の 有意相関が認められた $(\mathrm{r}=-0.586, P<0.01, \mathrm{~N}=20)$. その日の最高気温 $12^{\circ} \mathrm{C}$ 以下では ほぼ一定 (189-195 分) で, $12^{\circ} \mathrm{C}$ を越光ると温度の上昇にほぼ反比例して短縮した.

以上から, 集合率・集合の回数と個体数・集合所要時間・集合開始から就侍終了までの 時間・就侍開始時牤よび終了時の照度などと最高気温との関係を整理すれば，次のように なる。すすなわち, 気温が高いほど集合の開始時刻が遅くなり, 集合率が高く, 集合所要時 間が短く, 就侍開始時刻が遅くなった。これは気温が高いほど遅くまで採食地にいて採食 度の個体差が縮まり, 短時間に集中的に集合してくることを示すものと考学られる. いっ ぽう, 気温の低い日は就侍が早目に行われる。例えば, 1 月 22 日や 2 月 19 日のように 寒さがきびしい日には集合所の引き払いが早く, 照度も高く, 集合率も低かったが, 就侍 個体はいまだ一定の採食度に達しないものが多いと推定された (Fig. 1).

v) 気温と林での集合部位

林で集合の行われた方位とその日の風向・風速・最高温度の関係を, Table 1 に示す. この林は周辺の地域よりも高い位置にあって, 冬季は季節風にさらされる. 風向としては 調查の 22 日間を通じてW (西)・N (北) が卓越している. いっぽう, 集合の行われた林 の方位は東 11 日, 西 4 日, 南 1 日, 東十西 3 日, 東十西十南 1 日, 東十南 1 日, 西十南 1 日で, 東が用いられなかったのは 6 日間だけである.

$\mathrm{W} \cdot \mathrm{N}$ の風を避ける林の方位は東・南であるから, 風を避けたと思われないのは 12 月 中と 3 月 19 日以後での 23 日 $\left(10.5^{\circ} \mathrm{C}\right)$ 以外の日日で, これらの日日の最高気温は $13.1^{\circ} \mathrm{C}$ 以上であった．そして，林での集合部位は 12 月と 3 月 23 日以後（計 7 日）は林冠部 で，他はすべて林の中層（季節風に対する死角部）であった，な拈，侍には外敵に対する 安全性のほかに, 防寒に有利な部位が選ばれていた（伊藤，1984）. 
Table 1. The effect of wind direction on the location of the roosting assembly.

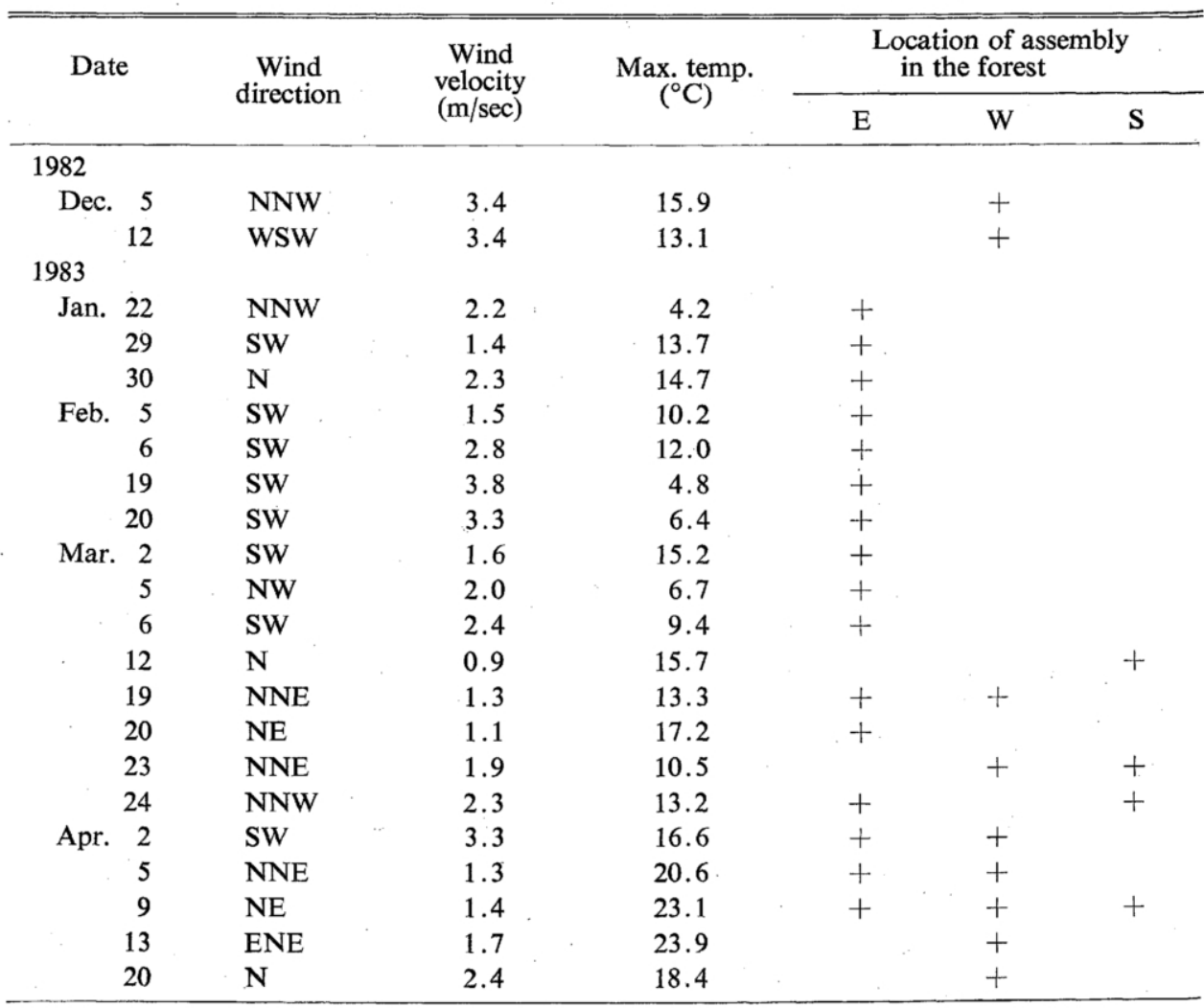

（4）就侍行動と天候

百間川河口で 1981 年に天気の異なる 3 日を選んで観察した結果は, 10 月 7 日（雨）は 集合時間 15 時 30 分一 17 時 15 分, 照度 4,000-0 lux, 集合数 52 羽, 集合回数 21 回; 10 月 17 日 (量) は集合時間 15 時 10 分一17 時 39 分, 照度 4,500-0 lux, 集合数 70 羽, 集合回数 14 回；10月 18 日 (晴) は集合時間 15 時-17 時 47 分, 照度 5,500-0 lux, 集合数 80 羽, 集合回数 25 回であって, 集合に対し雨の直接的影響は認められなかった.

垂仁天皇陵で天気の異なる 2 日について観察した結果は, 1983 年 3 月 20 日（晴のち 晨) は集合時間 16 時 1 分-18 時 25 分, 照度 9,310-444 lux, 集合数 435 羽, 集合回数 145 回に対し, 同 23 日 (13 時まで雨, 13 時 30 分一-15 時濃霧) には集合時間 15 時 14 分-18 時 27 分, 照度 13,630-282 lux, 集合数 465 羽, 集合回数 142 回で, 濃霧の影響 はとくに認められなかった。

さらに, 三島池で, 1982 年 11 月 28 日 (晴) には, 集合時間 14 時 10 分一16 時 58 分, 照度 6,500-100 lux, 集合数 56 羽, 集合回数 31 回で, 1983 年 1 月 9 日 (雪, 風速 10-15 m/sec 筆者測定) には集合時間 13 時 30 分一17 時 30 分, 照度 4,000-0 lux, 集合 数 99 羽, 集合回数 49 回であって, 集合に対し明らかな雪の影響は観察されなかった.

このように，それに伴う照度変化の影響は別として，直接雨・霧・雪などの天候条件の 集合に対する影響と認めるべき事実は，観察した限りでは見出せなかった， 
ただし，1983 年 3 月 6 日 (晴一時雨), 垂仁天皇陵で降雨に際し照度が 5,580 lux から にわかに 340 lux に低下した 15 時 14 分に, コサギが集合所に集結し始め, 16 時 15 分 までに 46 羽となり, 天気が回復して 16 時 41 分に照度が 10,750 lux に上昇したとき全 部が飛去した。 また, 1982 年 7 月 25 日牧野町中庄で, 14 時にわか雨に伴ら照度の著し い低下のとき, 約 150 羽のコサギがいったん侍の木に帰ったが, 雨が止み照度が上昇した とき飛去した，このような行動は，前記のと扮り降雨だけでは観察されなかったので, 雨 に伴う照度低下により㷌侍行動が招来されたものと解したい。

\section{（5）離侍前活動}

水鳥で離侍前活動 (pre-flight activity; BLACKBILL, 1952) と呼ばれている離侍前の水浴び や潜水・羽ばたきなどに類した行動が，冬侍のコサギについても観察されている（柿沢・ 柿沢, 1973). 朝の目ざめ前から離侍終了に至る行動の 1 例として, 1983 年 3 月 6 日の結 果を Table 2 に示した.

冬侍でのコサギは必ずしも終夜沈黙しているわけではなく，深夜でも「クワッ,クワッ」 という鳴き声が調査の 2 日とも 1 時間のうちに 2 回ずつ聞壳たが，それは朝の離持前の鳴 き声に比ぺて小さく，1 羽の発声と思われた。 また，小競り合いを思わせる鳴き声が 1 日 だけ聞えた.

Table 2. An example of pre-flight activities at the roost, between first call and termination of departure on 6 March 1983.

\begin{tabular}{|c|c|c|c|c|c|}
\hline Time & $\begin{array}{l}\text { Behaviour } \\
\text { (no. of egrets) }\end{array}$ & $\begin{array}{l}\text { Light } \\
\text { intensity } \\
\text { (lux) }\end{array}$ & Time & $\begin{array}{l}\text { Behaviour } \\
\text { (no. of egrets) }\end{array}$ & $\begin{array}{c}\text { Light } \\
\text { intensity } \\
\text { (lux) }\end{array}$ \\
\hline $5: 23$ & G & 0.00 & $6: 05$ & 10Qs, flapping (4) & 6.93 \\
\hline 36 & 2Gs, ${ }^{*}$ awakening (1) & & 06 & moving to the top & 8.96 \\
\hline 46 & Awakening (almost all) & & & of the tree (many) & \\
\hline 47 & & & 07 & $1^{* *}$, start of departure & 11.31 \\
\hline 48 & Head moving (4) & & 08 & & 13.76 \\
\hline 49 & G & 0.20 & 09 & $1,1,1,1,1,1,1$ & 17.27 \\
\hline 50 & $2 \mathrm{Qs} *$ & & 10 & $1,1,1,1,1$ & 22.20 \\
\hline 51 & $2 \mathrm{Qs}$, preening & & 11 & $1,1,1,1,3$ & 26.80 \\
\hline 52 & $4 \mathrm{Qs}$ & & 12 & $2,1,1,1,1$ & 33.60 \\
\hline 53 & $3 \mathrm{Qs}$ & & 13 & 1,1 & 42.50 \\
\hline 54 & & & 14 & ca. $200,1,2$ & 53.00 \\
\hline 55 & 7Qs & 0.65 & 15 & ca. $300,1,3$ & 66.90 \\
\hline 56 & $3 \mathrm{Qs}$ & & 16 & ca. $100,6,2,3$ & 81.90 \\
\hline 57 & & & 17 & $1,1,1$ & 104.10 \\
\hline 58 & $10 \mathrm{Qs}$ & & 18 & 50 & 127.00 \\
\hline 59 & & & 19 & 20,19 & 149.70 \\
\hline 6:00 & 7Qs & 2.10 & 20 & $4,1,2,2,1,1,1$ & 176.70 \\
\hline 01 & & 2.99 & 21 & 3 & 205.00 \\
\hline 02 & & 3.55 & $\ldots$ & & Sunrise \\
\hline 03 & $10 Q s$ & 4.26 & 22 & 2 , termination of depar & ure \\
\hline 04 & Flapping (1) & 5.41 & & & 235.00 \\
\hline
\end{tabular}

*G="goah" call; $\mathrm{Q}=$ "qua-qua" call. $\quad{ }^{* *}$ No. of leaving individuals. 


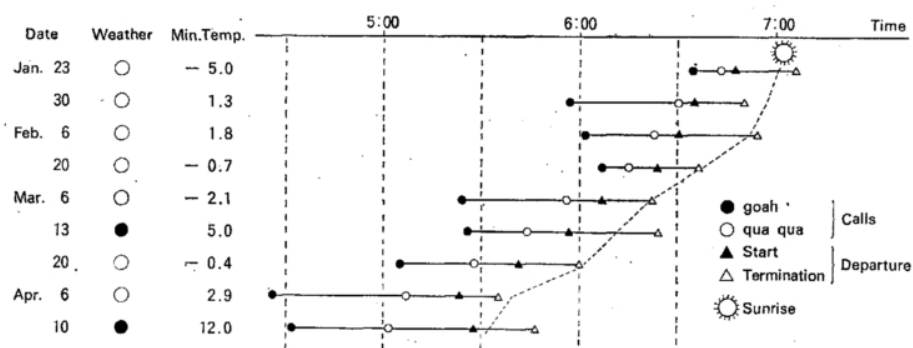

Fig. 4. The sequence of behaviours associated with departure in relation to sunrise.

早朝に林内の埘位置から「ゴアー」とあとを長くひく鳴き声 (1 羽の発声と思われる) が聞壳てくると, ほどなく梢の個体の目ざめ（垂れていた首をるたげる）が始まり, 静 止・整羽・羽ばたき・羽ばたさによる場所移動が観察され, やがて目ざめの個体数がまた たく間に増光，林内から梢への枝移りが目立つようになる。しかし，上空飛翔は観察され なかった.「ゴアー」の間隔が次第に縮まり, 鳴き声はやがて「クワッ,クワッ」に変り, 更に「クワッ, クワッ, クワッ」といっせいに鳴くようになる. な拈，早朝の第 1 声は 4 月 17 日と 5 月 19 日には「ゴアー」でなく,「クワッ, クワッ」であった. Fig. 4 に調 查 9 日間の離侍行動の経過を天候・最低気温とともに示す. 早朝の「ゴアー」という発声 開始は冬侍での離侍前活動の始まりの有効な指標と考えられるが，その時刻は日の出前平 均 40.2 分 (60-10 分, $\mathrm{SD}= \pm 17.2$ 分, $\mathrm{N}=9)$ であった.

発声開始から離塒開始までを離侍前活動期 (pre-flight activity period) と呼ぶことにする. 離侍前活動期は平均 35.2 分 (13-56 分, $\mathrm{SD}= \pm 14.3$ 分, $\mathrm{N}=9$ ) で, その日の最低気温と の間に正相関の傾向 $(\mathrm{r}=0.674,0.05<P<0.06, \mathrm{~N}=9)$ が認められた. な括,「クワッ, ク ワッ」の始まりから離侍開始までは平均 11.2 分 (4-26 分, $\mathrm{SD}= \pm 6.1$ 分, $\mathrm{N}=9$ ) であっ た.

\section{（6）離 侍}

離侍は Table 2 に示したパターンで行われた，すなわち，いきなり多くの個体が同時的 に飛び立つことは 1 日もなく, 飛び立ちの開始は 1 羽か 1 羽ずつのばらばらであった. 1 , 2, 3，5，7，10 羽などのわりあいに少ない数での飛び立ちの間に，いちどに飛び立つ群れ があった. 調査日ごとの 30 羽以上の群れの数を示せば, 1 群の日が 1 日, 3 群の日が 2 日， 4 群の日が 6 日で, 多くは 4 群であった。 また群れのサイズ (㧊よその数) 別の度数 を示せば， 100 羽が $8 ， 50$ 羽和よび 200 羽が各 5, 30 羽が 3, 60 羽特よび 70 羽が各 2, 150 羽, 250 羽, 300 羽, 350 羽, 400 羽, 550 羽が各 1 で, 50, 100, 200 羽の群れ が大半を占めた.

柿沢・柿沢 (1973) は最初の 1 羽が飛び立ってもあとが続かないとき飛び立った 1 羽が 侍のまわりをジグザグに飛ぶのを認め, 飛び立ちの誘いかけであろらと解して fluttering と呼んでいるが, 私はこの行動を観察しなかった.

離侍開始の時刻は日の出前平均 16.1 分 (22-5 分, $\mathrm{SD}= \pm 5.0$ 分, $\mathrm{N}=9$ ), 照度は平均 $14.3 \operatorname{lux}(2-50 \mathrm{lux}, \mathrm{SD}= \pm 14.9 \mathrm{lux}, \mathrm{N}=9)$ で, 離侍終了の時刻は平均して日の出前 2.1 分 (日の出前 7 分一日の出後 14 分, $\mathrm{SD}= \pm 6.4$ 分, $\mathrm{N}=9$ ), 照度は平均 $393.4 \operatorname{lux}(30-1,400$ lux, $\mathrm{SD}= \pm 468.2 \mathrm{lux}, \mathrm{N}=9)$ で, 離侍所要時間は平均 18.2 分 $(12-27$ 分, $\mathrm{SD}= \pm 4.8$ 分, 


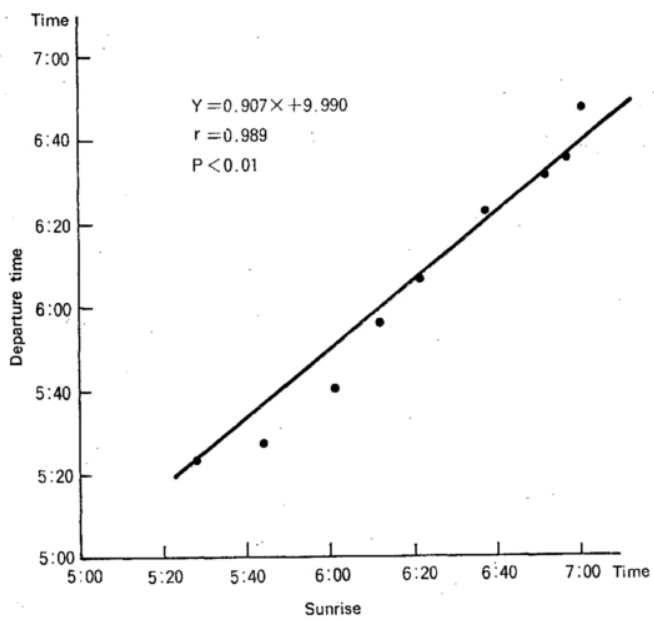

Fig. 5. The relationship between departure from the roost and sunrise.

N=9) であった.

離侍開始時刻は日の出時刻との間に強い相関関係 $(\mathrm{r}=0.989, P<0.01, \mathrm{~N}=9)$ があり (fig. $5)$, 最低気温との間に負相関 $(r=-0.706,0.02<P<0.05, N=9)$ が梕められた.

雨天の 2 月 13 日, 4 月 10 日では離侍終了がそれぞれ日の出後 11,14 分で, 平均（日 の出前 2.1 分）からの遅れが目立った (Fig. 4)。しかし離侍終了時の照度はそれぞれ 153, 77 lux で, 後述の結永の朝以外の日と目立った差がない. これは前記 (p. 58) の雨に伴 ら照度の低下に際して観察された非常に早い時刻での帰侍行動とあわせ考兄, 直接雨のた めといらよりは, 雨に伴ら照度上昇の遅れのためと考えられる.

\section{（7）離侍後の行動}

観察 9 日のうち 8 日では離埘ののちまっすぐに採食地に向かったが, 1 日だけ特異な行 動が観察された.

i) 一般的な行動

一般的な行動の 1 例として 2 月 20 日朝の離侍後の行動を示すと, 全数 693 羽のらち 680 羽が南の方向に飛去したが，その約 70\% は 3 回の大群で飛び立った. そして， $300 \mathrm{~m}$ を越えると次第に分散し，1,200 m までに $45.5 \%$ が降下したが， 371 羽はさらに南へ飛去 した．飛び立ちのとさと $1,200 \mathrm{~m}$ 地点通過時の個体数別の頻度は Fig. 6 亿示すとおりで, 1 羽の頻度は飛び立ちのとき約 $15 \%, 1,200 \mathrm{~m}$ 地点通過時では約 $40 \%$ で, 群れで飛び立 っても早い時期に分散するものと想定された.

ii) 特異な行動

最低気温が $-5^{\circ} \mathrm{C}$ で侍の前の周㴚が著しく結氷した 1 月 23 日だけに, 飛び立ち後の特 異な行動が観察された. Fig. 7 に示す如く, 6 時 47 分飞離壂が始まり, 235 羽が 55 回 の飛び立ちで出発したのち， 7 時 4 分いっきょに 351 羽が飛び立ったが, ·約 $100 \mathrm{~m}$ 去っ たところで, 183 羽 (全数の $31.3 \%$ ) が引き返し，21，37，125 羽の 3 群に分かれて, 前 日の就侍前集合の（林の東側と南側で, 日当りがよい）場所に集結し，そのあと 3 時間に わたり分散的に飛び立った.な拈，この日の離㘲の終了は日の出後 5 分で, 照度は 1,400 


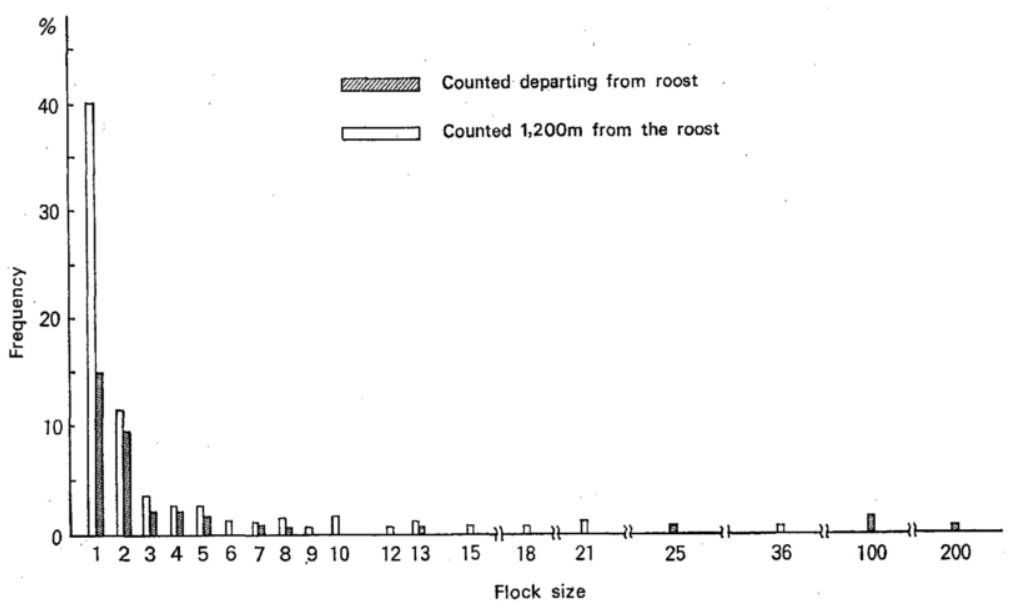

Fig. 6. The frequency distribution of flock size, at departure from the roost.

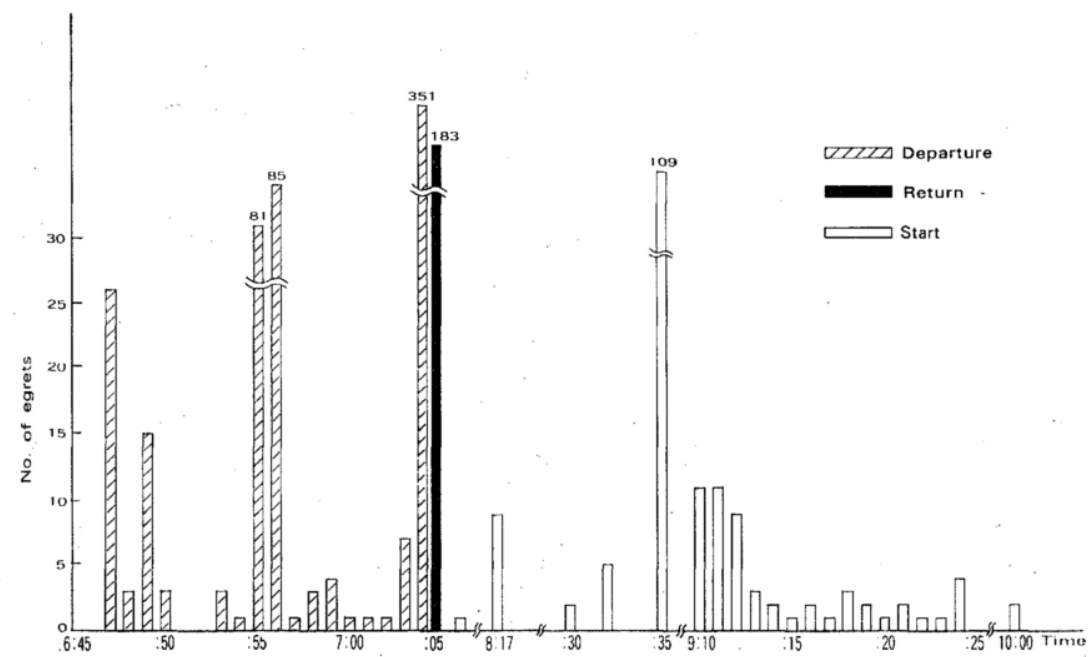

Fig. 7. Departure from the roost and return to the forest on a very cold morning (temp. $=$ $\left.-5^{\circ} \mathrm{C}\right) 23$ January 1983.

lux であった。 これは, 最低気温と離坿終了時の照度の間に認められた負の相関傾向 $(\mathrm{r}=$ $-0.603,0.05<P<0.06, \mathrm{~N}=9$ ), すなわち気温が低いほど離侍終了時の照度の高い傾向が 明瞭に示されたものと考えられる。

（1）就侍行動之気象要因

就侍前集合・就侍ともに開始時刻が日没時刻との間に正相関（それぞれ $\mathrm{r}=0.686, \mathrm{r}=$ 0.852) があり, 降雨に伴う照度の急な低下に際して異常に早い時刻（いわば採食度とは 無関係) に行われた帰侍行動からみても, 就侍行動は種種の複合条件に影響されるとはい 
え，照度がまずその主要な要因だと想定される.

就侍要因としての照度については, 夏季侍のスミレサギ Florida Caerulea, ダイサギ Casmeroidius albus，ササゴイ Butorides virescens (SEIBERT, 1951) で日没時刻, ハシボソ ガラス Corvus crone とハシブトガラス C. macrorhynchos（山岸，1962）で明るさが指摘 され，柿沢・柿沢（1973） は冬侍のコサギの帰侍時刻が基本的には明るさによって決定さ れると報告している.

照度以外の要因は何か. 集合開始から就侍終了までの時間の幅が大きいこと（平均 155.8 分）（伊藤，1984）は, 一定の採食度を得る上での個体差の反映だと解され, 帰侍要 因として採食度が考えられる．帰侍要因としての採食度はホシムクドリ Sturunus vulgaris (BRowN, 1946)，ムクドリ Sturunus cineraceus (黒田, 1961)，トビ Milvus migrans (羽田 ほか, 1966) でも考学られている。

いっぽう, 就壀開始時の照度と最高気温の間には負相関があって, 最高気温が低いほど 高い照度で就侍が始まる．また，寒いあいだ林での集合部位として季節風の死角部が選ば れ, 侍部位の選択条件として外敵の接近し難いことのほかに防寒性が考えられたことから (伊藤, 1984), 気温が就侍に対して強く作用していることが示唆される. 重野 (1983) もシ ラサギの冬季の帰侍行動について, 寒冷日には侍への飛来が温かな日よりも早くなると述 べ, 温かな日のように梢に止まらないとも報じている。このように, 同じ時刻まで採食し なければ一定の採食度が得られないと仮定するなら, 気温が低ければ就侍時刻が早くなっ たので, 空腹度を満たす欲求よりも, 就侍を促す気温の要因の方が強いと考えられる。 とめると, 冬侍のコサギの就侍行動に対しひきがね的に作用する要因は照度（日没）であ って，それに気温と採食度がさらに微調整し，この後 2 者のらちでは気温の方が大きく影 響するのではないかと思われる。

\section{（2）離侍行動と気象要因}

「クワッ, クワッ」という鳴き声の開始時の照度が 0.1-0.6 lux で, これょりも24.0 分早 い「ゴアー」の発声開始時点の照度はまだ 0 lux よりも低かったが, 目ざめ・飛び立ちの 時刻が林で西側よりもわずかでも明るい南側の方で早かったこと, 雨に伴う照度低下に際 して離侍終了が遅れたことなどから, 活動開始の要因は明るさだと考兄られる. しかる， 離侍の開始時刻と日の出時刻の強い相関関係 $(\mathrm{r}=0.989)$ からみれば, 離侍に対してひきが ねとなっている要因は明るさだと想定される，これは，離墛時刻が日の出時刻によって決 定されるという柿沢・柿沢 (1973) の報告を定量的に確かめたことにもなる. なお, SEIBERT (1951) は, 夏季侍について日の出時刻が 3 種のサギの離侍時刻を規制する最も重要な要 因だと報告している.

私の定量的調査では, 気温が低いほど, 目ざめから離埘開始までの時間が短くなる傾向 があり, かつ離侍開始時刻が早くなった。 また, 最低気温と離侍開始から終了までの時間 には有意相関が認められなかった $(r=0.210, P>0.1, N=9)$.これは, 柿沢・柿沢 (1973) が定性的調查で, 気温が $0^{\circ} \mathrm{C}$ に近いかそれ以下になると飛び立ちが日の出から何時間も遅 くなるといい, 重野 (1983) が寒さがきびしい日は離侍が遅くなり, 離侍の開始から終了ま での時間が長いと記載していることとは違った結果であるが，低温でエネルー需要が高ま るために空腹の個体の採食地への飛び立ちが早くなるものと考察される. SEIBERT (1951) は, 夏季夜間に就侍するサギについて気温が低くなった翌朝の飛び立ちが早いことを観察 
して, やはりェネルギー需要の高まりと結びつけて考えている.

以上のことから, 冬侍のコサギの離垹のおむな要因として照度・気温・空腹の 3 つが考 党られるが，ひきがねとして作用する要因は照度（日の出）であって，それに気温と空腹 がさらに微調整し，この2者のらちでは気温が強く働くものと考觉られる.

(3) 結水飞対する適応行動

最低気温が $-5^{\circ} \mathrm{C}$ で周儫が厚く結氷した朝観察された離侍後の特異な行動は, 最低気 温が $0^{\circ} \mathrm{C}$ 以下でも周濠の結水しない 4 日では観察されなかった. すでに柿沢・柿沢 (1973) もいったん飛び立ったコサギが結氷の時期に時に戻ってくることを観察し, 結氷の朝の飛 び立ちの時刻が氷のとけ始める時刻とかなり一致すると述べている．この行動は, 単に厳 寒を避けたというよりは結水に対する適応行動だと解するのが妥当だと思われる.

気温が低ければ離侍開始が早くなるのであるが，結氷が著しければ，このようにして採 食地への到着が遅れる個体も多くなる. しかも, 気温が低いとき就侍時刻も早くなるの で, 採食時間がいよいよ短縮するきびしい結果となる，今後, こうしたきびしい状況下で, コサギがどのように採食の時間配分をしているのかを精査する必要があろう.

（4）気象要因についての就時と離侍の比較

就侍と離侍についてひきがねとなるのは，それぞれ日没と日の出に伴う明るさであっ て, 就埘開始は平均して日没後 3.3 分で, 照度は平均 355.2 lux, 離侍開始は日の出前平 均 16.1 分で照度は平均 14.3 lux であった.

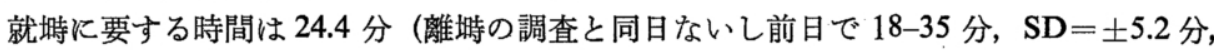
$\mathrm{N}=9)$, 離侍に要する時間は 18.2 分で, 有意の $(0.02<P<0.05)$ 差はあったが, ともに短 い.すなわち, 離侍・就侍とるに短時間に一斉に行われた. 離侍が州侍に比べて短時間に 一斉に行われるといら報告（重野，1970；山岸ほか，1980）があるが，私の結果では集合 の開始から就侍終了までは 155.8 分であったので (伊藤, 1984), これらの報告では侍の ごく近くで集合をしていることに気がつかずに，集合から就侍終了までの時間を就侍時間 と捉えたため，そのような解釈になったものと思われる。

コサギは朝目ざめて直ちに離侍するのではなく, また夕刻も集合を経て一定の照度に達 してはじめて就侍する個体が多かったことから, 就・離侍には照度の一定の閾值があり, かつ離侍の閾値の方が就侍の闘值よりもずっと低いことは, 空腹での離侍に対する衝動の 方が, 一定の採食度を得たらえでの就埘に対する衝動よりも強いためであろう.

また，離侍行動には就侍行動に括ける集合（タイプ B·C で 128.0 分）（伊藤, 1984) に対応するステップがない. 強いて求めるならば，それは著しい結氷に際して観察され た, 結氷に対する適応行動であろう。しかし, これは一般的ではなく, 普通は侍からいき なり採食地へ向から.したがって, たとえ離侍前活動期 (35.2 分) を加えても一連の離侍 行動は就侍行動に比べたいへん短い時間で終る、それは朝の空腹の度合には個体差がほと んどなく, 平均的な空腹状態にあるためだと考兄られる.なお, 就侍・離侍の両面から, 気温が低いほど彼等は 1 羽ずつに分散する傾向が認められ, 寒冷に対するひとつの適応行 動ではないかと考兄られたが，その意義は今後の解明に待ちたい。 
この研究にあたり贵重な示唆を賜り，かつこの論文の校閲をしていただいた大阪市立大学理学部生 物学教室の山岸哲博士に対して厚く感謝の意を表する. さらに三好 忞・神原博輝・手塚 稔の 3 氏 に観察を, 大阪市立大学理学研究科大学院生上田恵介氏に英文作製を手伝っていただいた. また文献 については, 井上良和・重野保博の両氏拈よび山階鳥類研究所の柴田敏隆・柿沢亮三・岡奈理子の 3 氏に打話になった。 あわせて謝意を表したい。

\section{摘要}

1982 年 12 月から 1983 年 5 月にかけて, 奈良市・垂云天皇陵のコサギの冬侍において就・離㭙 行動と気象要因の関連を調査して, 次の結果を得た。

（1）冬侍に淤るるコザの就・離侍行動は，照度がひきがね的要因となり，それに気温と採食度 ないし空腹度がさらに微調整し, 後 2 者のらちで気温の方が大きく影響するものと考えた.

（2）離侍開始時（日の出前平均 16.1 分）の照度（平均 14.3 lux）は, 就侍開始時 (平均して日 没後 3.3 分）の照度（平均 355.2 lux） よりも低かった.

(3) 離侍終了時 (平均して日の出前 2.1 分) の照度（平均 393.4 lux） は, 就跱終了時（日没後 平均 19.6 分) の照度 (平均 4.7 lux) よりも高かった.

（4）就侍と離侍はともに短時間に一斉に行われたが, 就侍に要する時間 (24.4 分) は, 離侍に要 する時間（18.2 分）よりも長い. 就侍前集合（128.0 分）飞始まる一連の就侍行動には，離侍前活動 (35.2 分) 飞始まる一連の離侍行動よりもはるかに長い時間がかかった.

（5）気温が低い汪ど採食地で分散傾向のあることが示唆された.

（6）就侍行動と気象要因の関連につき分析して；次の結果を得た.

(i) 就侍前集合の開始時刻は平均して日没前 125.3 分で, 照度は $80 \%$ が 14,000 lux 以下であっ た. (ii) 就侍前集合数の $70 \%$ が集合したときの照度は, $75.0 \%$ の調査日で 700 lux 以下であった. (iii) 気温が高いほど，上り多くの個体が，より短い時間に，ょり少ない飛来回数で就侍前集合し，就 侍時刻は遅くなった，(iv) 林での集合部位には，気温の低いあいた゚季節風の死角部が選ばれた。（v) 就侍前集合に対する雨・霧・雪の直接的影響は, とくに認められなかった.

(7) 離侍行動と気象要因の関連につき分析して, 次の結果を得た。

(i) コサギには離船前活動期 (平均 35.2 分) があり，早朝飞㭙位置から聞えてくる「ゴアー」と いら鳴き声が離侍前活動開始の有効な指標である. (ii) 離侍前活動は平均して日の出前 40.2 分 (照 度は０ｌux よりる低い）に始まった（iii) 気温が低ければ離侍の開始が早くなった（iv）気温が低 ければ離侍前活動期が短い傾向があった（v) 結氷の強い朝, いったん離侍してから侍の所在する林 に引返して何時間もかけて採食地へ飛び立つといら, 結水に対する適応と思われる行動が認められた. （vi）離侍の開始は単独飛び立ちであり，大きな群れで飛び立っても早い時期に分散する. (vii) 雨の ために照度が低下すれば, 離侍終了が遅れた。

\section{SUMMARY}

The effects of weather on arrival and departure from the roost by Little Egrets Egretta garzetta, were investigated between December 1982 and May 1983, at a winter roost, at Suinin-tenno Mausoleum, Nara City, Japan.

(1) Light intensity seems to be the most important factor affecting both arrival at and departure from the roost. Additional factors were temperature, foraging rate, and hunger level, of which temperature seems to be the most important.

(2) The mean light intensity at the start of departure (14.3 lux, $16.1 \mathrm{~min}$ before sunrise) was lower than at the start of arrival at the roost (355.2 lux, 3.3 min after sunset). 
(3) The mean light intensity at the termination of departure (393.4 lux, $2.1 \mathrm{~min}$ before sunrise) was higher than that for arrival (4.7 lux, $19.6 \mathrm{~min}$ after sunset).

(4) Both the mean time spent for arrival (24.4 min) and that for departure (18.2 min) were short; however, the former was significantly different from the latter. Time spent for a series of roosting behaviours (including pre-roosting assembly) was much longer than that for departure (including pre-flight activities).

(5) The lower the temperature, the more widely egrets scattered over the foraging site.

(6) (i) Gathering at pre-roosting assemblies started $125.3 \mathrm{~min}$ before sunset on average. The light intensity at the time of these gatherings was below 14,000 lux (for $80 \%$ of the gatherings). (ii) Light intensity was 700 lux and below when $70 \%$ of pre-roosting birds had gathered, on three quarters of all observation days. (iii) Arrival at the roost began earlier on extremely cold days, and was delayed on days of high temperatures. In warm days, more individuals arrived in large flocks over a shorter time. (iv) Egrets chose sites where were not exposed to wind for pre-roosting assembly in the forest during the cold season. (v) No effect of rain, snow, or fog was observed on pre-roosting assembly.

(7) (i) Pre-flight activity began with "goah" calls in the roost. (ii) Activity started $40.2 \mathrm{~min}$ before sunrise when the light intensity was below 0 lux, and lasted for $35.2 \mathrm{~min}$. (iii) Departure was hastened by low temperature. (iv) Low temperature shortened the pre-flight activity period. (v) Some departing flocks returned to the forest on freezing morning, stayed in the forest for several hours then left again for foraging sites. (vi) Departure from the roost started with a single individual. Large flocks dispersed immediately after departure from the roost. (vii) Decreasing light intensity caused by rain delayed the termination of departure.

\section{引用 文 献}

BlaCKBILl, H., 1952. Light intensity and Waterfowl flight; pre-flight activities. Wilson Bull., 64: 242-244.

BRown, F. J., 1946. A cheshire starling roost, 1944-5. J. anim. Ecol., 15: 75-81.

黒田長久，1961。 ムクドリの帰持行動とその影響要因について. 日生態会誌，11：26-34.

羽田健三・小泉光弘・小林建夫, 1966. トビの生活史に関する研究， II. 非繁殖期 (1). 日生態会誌, 16: $71-78$.

伊藤信義, 1984. コサギの就侍前集合. 鳥, 33: 13-28.

杮沢亮三・柿沢佳子，1973. コサギ (Egretta garzetta) の冬侍における生活. 長岡市立科学博物館研 究報告, (8) : 17-26.

環境庁，鳥類観測ステーション運営綜合解析報告. 1978: 246 .

日本気象協会奈良支部, 1982, 1983. 奈良県気象月報.

日本鳥学会, 1974. 日本鳥類目録. 改訂 5 版. 東京, 学習研究社.

SeIBert, H. C., 1951. Light intensity and the roosting flight of herons in New Jersey. $A u k, 68$ : 63-74.

重野保博, 1970. 仁德陵及び御廟山におけるサギュロニーの生態. 日本生物教育学会第 25 回全国大 会記念誌：139-149.

1983. 堺・泉北地帯に拉けるサギュロニーの生態. 大阪府生物研究会発表資料.

山岸 哲, 1962. カラスの就侍行動について, 第 1 報長野県下での秋冬の時について. 日生態会誌, 12: 54-59.

山岸 哲・井上良和・米田重玄, 1980. 奈良盆地に拈けるサギ類の集団繁殖地と塒の配置拈よび採食 範囲. 鳥, 29: 69-85. 